\title{
116. 色差評価における高齢者のカテゴリ一尺度
}

\author{
神農 悠聖 \\ 岩田 三千子 \\ 長町 章夫 \\ (摂南大学・大手前大学) \\ (摂南大学) \\ （株式会社 CIJ）
}

\section{1.研究の目的}

快適な視環境の整備に関する研究では、人の応答による心理評価には通常カテゴリー尺度が用いら れる。この場合、刺激に対応した尺度は被験者個人の判断基準に依存して選択され、高齢者を被験者 とした場合に、青年を被験者とした場合とは判断基準の傾向が違うことが知られている。そこで、本 研究では、高齢者の被験者を対象とした場合の色差評価に選択されるカテゴリー尺度について、青年 との結果を比較し検討した。

\section{2 . 実験概要}

青年 15 人 $(20 \sim 23$ 歳: 平均 21.7 歳) と、高齢者 16 人（64７5 歳: 平均 67.6 歳）を被験者とした。

明度、彩度 (赤・緑・黄・青) の 5 種類の系統の視 標の色を $\mathrm{L}^{*} \mathrm{a}$ *b*表色系の值から計算し表示するプロ グラムを作成し、CRT ディスプレイに図 1 のように呈 示して、実験 I ・実験IIの 2 種類の実験を行った。図 1 の視標 $\mathrm{A}$ の色は下限值、Cの色は上限值で、この間 を 0 〜 の值で刺激値として定義する。

実験 I では被験者に視標 B の色を調整させ、呈示され た程度表現語に合う色差を作り出させた。

実験 II では B の刺激值（色）をランダムに呈示し、 表 1 の逆順に並べて表示した評価言語の中から A と B の色差を表すのに適切なものを選択させた。

\section{3. 結果}

図 2 に実験 I より求められた刺激值の中央值を示す。 青年は全ての系統で「21 非常に…」が 0.9 を超えている のに対し、高齢者は明度で 0.55 と低かった。また、高齢 者は「01 まったく でが青年に比べて低かった。このことから高齢者はより 刺激が小さい場合しか「…ない」という評価を使用しな いことがわかった。また、青年、高歯者とも彩度(赤)と(緑)、 彩度(黄)と(青)が同じ傾向を示していることがわかった。 その $2 つ の$ 系統の差は高齢者が大きかった。

実験ILよ、色差と評価言語の選択の関係について、 青年は視標の系統の違いによる差が小さいのに対し、高 齢者は明度において「18たいへん‥」〜「21 非常に…」 の評価言語の使用頻度が高いことがわかった。逆に、彩 度(黄)・彩度(青)においてはこれらの評価言語の使用頻度 が低いことがわかった。

青年は各系統で実際の色差に関わらず最低值と最高值 に基づく刺激值により評価言語を選択する傾向が認めら れたが、高齢者では実際の色差值をより重視して評価言 語を選択する傾向が認められた。

表 1 実験で使用した評価言語

\begin{tabular}{|c|c|}
\hline 01まったく 差がない & 12 多少 差がある \\
\hline 02 ほとんど 差がない & 13 わりに 差がある \\
\hline 03たいして 差がない & 14 だいぶ 差がある \\
\hline 04 あまり 差がない & 15 かなり 差がある \\
\hline 05 それほど 差がない & 16 とても 差がある \\
\hline 06 どちらかといえば 差がない & 17 そうとう 差がある \\
\hline 07 どちらかといえば 差がある & 18 たいへん 差がある \\
\hline 08わずかに 差がある & 19 きわめて 差がある \\
\hline 09少し 差がある & 20 すごく 差がある \\
\hline 10いくらか 差がある & 21非常に 差がある \\
\hline 11 やや 差がある & \\
\hline
\end{tabular}

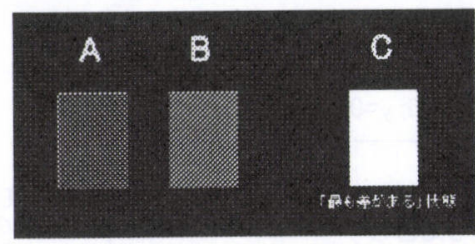

図 1 実験に用いた視標例

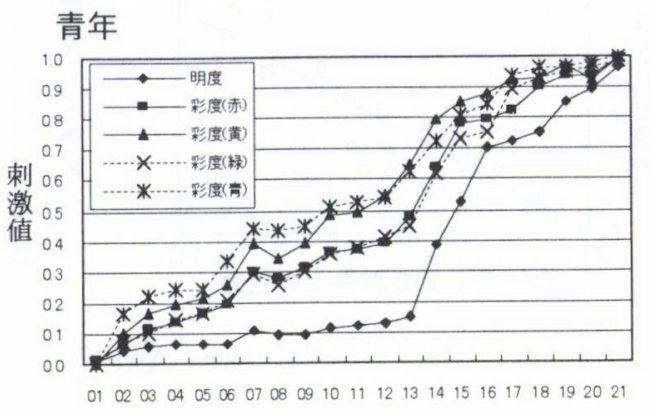
高齢者

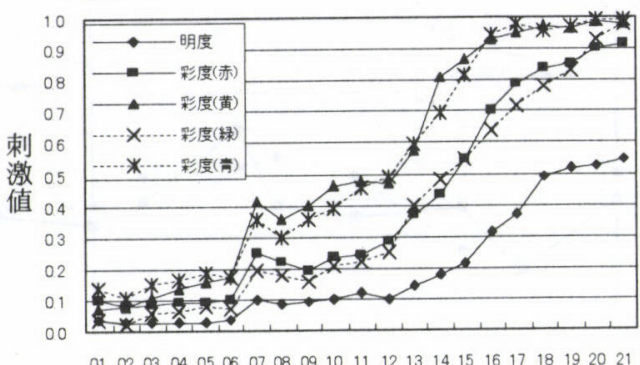

評価言語

図2 実験Iより算出した評価言語の強さ

Study on the category scale by color difference evaluation for the elderly KONO Masami, IWATA Michico and NAGAMACHI Akio 